\title{
BACKGROUND AND MANAGERIAL PRACTICE OF NURSES: PATHS FOR TRANSFORMING PRAXIS ${ }^{1}$
}

\author{
Zélia Marilda Rodrigues Resck ${ }^{2}$ \\ Elizabeth Laus Ribas Gomes ${ }^{3}$
}

Resck ZMR, Gomes ELR. Background and managerial practice of nurses: paths for transforming praxis. Rev Latino-am Enfermagem 2008 janeiro-fevereiro; 16(1):71-7.

Qualitative research using a dialectics view; the objective is to analyze the demands and the expectations from the setting of managerial practices in view of the Pedagogical Project and the strategies which may or may not favor the transforming praxis. It involves 11 students, 12 professors, and 12 service nurses who are the participants in the teaching-learning process of managerial knowledge, in the interceding space, in the fields of practice and in the curricular training programs, both in the hospital environment and in the basic health services and of the Nursing graduation course from a Federal University, from the city of Alfenas-MG. It uses the collecting technique by focal group and the analysis of the contents is subsided by two great discussions: background and work. The results point that the nurse's background and praxis must go through the work processes in the caring, managerial and educative dimensions as well as in the scientific investigation, building paths for the development of competences, in the teaching and service interaction, following the current National Curriculum Guidelines.

DESCRIPTORS: education, nursing; professional practice; professional competence; management

\section{LA FORMACIÓN Y LA PRÁCTICA GERENCIAL DEL ENFERMERO: CAMINOS PARA UNA PRAXIS TRANSFORMADORA}

Se trata de una investigación con enfoque cualitativo dentro de la perspectiva dialéctica; siendo el objetivo analizar las demandas y las expectativas de las prácticas gerenciales frente al Proyecto Pedagógico, así como las estrategias que favorecen la praxis transformadora. Participaron 11 alumnos, 12 docentes y 12 enfermeros del servicio, participantes del proceso enseñanza- aprendizaje en el saber gerencial del curso de Pre-grado en Enfermería de la Institución Federal de Enseñanza Superior de Alfenas-MG, en el lugar de intervención, en los campos prácticos y práctico curriculares del hospital dentro los servicios básicos. La recolección de datos fue a través del grupo focal y el análisis de contenido fue subsidiado por dos grandes vertientes: formación y actuación. Los resultados indican que la formación y la praxis del enfermero deben establecerse a través de procesos de trabajo en las dimensiones de cuidado, gerencial, educativa e investigativa, construyendo caminos para el desarrollo de competencias, enfatizando una mayor interacción entre la enseñanza y el servicio, de acuerdo con las actuales Directrices Nacionales Curriculares.

DESCRIPTORES: educación en enfermería; práctica profesional; competencia profesional; gerencia

\section{A FORMAÇÃO E A PRÁTICA GERENCIAL DO ENFERMEIRO: CAMINHOS PARA A PRÁXIS TRANSFORMADORA}

Pesquisa de abordagem qualitativa na perspectiva dialética, cujo objetivo foi analisar as demandas e as expectativas oriundas do cenário das práticas gerenciais, face ao Projeto Pedagógico e às estratégias que favoreçam ou não a práxis transformadora. Envolveu 11 alunos, 12 docentes e 12 enfermeiros de serviço, partícipes do processo ensino-aprendizagem do saber gerencial, no espaço intercessor, nos campos de prática e dos estágios curriculares, no ambiente hospitalar e nos serviços básicos de saúde e do curso de graduação em enfermagem, de uma Instituição Federal de Ensino Superior, da cidade de Alfenas, MG. Utilizou-se da técnica de coleta por grupo focal e da análise de conteúdo, subsidiada por duas grandes vertentes: formação e atuação. Os resultados apontam que a formação e a práxis do enfermeiro devem transitar entre os processos de trabalho nas dimensões cuidadora, gerencial, educativa e de investigação científica, construindo caminhos para o desenvolvimento de competências, com maior interação ensino e serviço, em atenção às Diretrizes Curriculares Nacionais atuais.

DESCRITORES: educação em enfermagem; prática profissional; competência profissional; gerência

${ }^{1}$ Paper extracted from Doctoral Dissertation; ${ }^{2}$ Adjunct Professor, Alfenas Federal University, MG, Brazil, Doctoral student, e-mail: zeliamarildar@bol.com.br; ${ }^{3}$ Associate Professor, e-mail: elaus@eerp.usp.br. University of São Paulo at Ribeirão Preto College of Nursing, WHO Collaborating Centre for Nursing Research Development, Brazil. 


\section{INTRODUCTION}

The dialectical relationship between Education, Health and Nursing Education, guided by Social Policies, has a tripod that shapes the education of nurses, whose knowledge is essential both for health professionals and those in education, engaged with the education of new nurse professionals. However, in the daily life of teaching, researching and taking care, in theory and practice of nurses, as well as other health professionals, this context is not always effective because of the technical-scientific education geared to the biomedical model and to alienation that values the work of doctors and disconnects it from the idea of team work $^{(1)}$.

The emphasis in the 21st century is in the transforming praxis that is characterized by indetermination and unpredictability, which enables men, as a conscious and social being, to face new needs and situations, and to produce something new from a reality or from preexisting elements, but, to that end there must be an intervention in conscious and in human action ${ }^{(2)}$.

To meet this challenge, Nursing must take a transforming theoretical-pedagogical reference that supports a significant learning, and that is suitable to the imposed social and professional demand. To that end, it is necessary to work with a different Pedagogy, that considers each learner with their potential and difficulties, and that aims at building senses, thus opening ways for transformation rather than the uncritical reproduction of social reality. To form this reference, contributions from all levels of society are searched for, in the work in itself and also in Pedagogy, Philosophy, Economics, and Social Science ${ }^{(3)}$.

The reference for education is practice, which is ideal for work, not as something far away, but as something created in a team project among partners. Thus, the importance of students being aware of reality, putting it into context, proposing different intervention plans and developing educational process for intervention meeting the social demands of every day life, is a cross sectional knowledge that is recovered in several moments ${ }^{(4)}$.

Managing knowledge is the o guide wire for nurses to search for professional development and to face challenges, not based on idealistic constructions made in the theoretical speech, but as a product of questioning, reflections, and studies performed every day, in the reality faced by the actors and partners in their praxis, represented here by the scholars of Nursing, professors and nurses of the member institutions ${ }^{(5)}$.

The present investigation centers in building management knowledge and conforming competences to nurses to take and conduct management work in health and in Nursing, with a transforming proposal.

The general objective presented is to assess the demands and the expectations from the scenery of management practices facing the Pedagogical Project, and the strategies involving professors, students, and nurses of the service which may or may not favor the transforming practice. And, as specific knowledge, to assess the management demands in the professional practice of nurses inserted in the process of organizing Health and Nurse work, according to Health Policies; to assess the building process of the management competences of nursing scholars during the Curricular Training, learning the limitations and strategies from the teaching-learning process, according to the current National Curriculum Guidelines.

\section{METHODOLOGY}

The choice for the investigative path in the approach of the empirical reality to reach the goals proposed in this study is the qualitative research.

The objectivity of the social phenomena regarding the subjectivity of meanings, attitudes, beliefs, and values are considered interdependent that is, the action and meaning interact. The research starts from the point of view of social actors, but it is not limited to them, encompassing relations that entail them and determine them. Likewise, the results of the investigations are unfinished and temporary, since there is no absolute truth, but historicity of social processes (object is historical), and the approximate character of qualitative approach ${ }^{(6)}$.

To that end, the theoretical reference we have adopted is based on the dialectic perspective, in which knowledge is a construction made as of other knowledge where apprehension, critic, and doubt are practice $^{(6)}$.

The option for the development field of this research is the scenery for the work of nurses, students, and nursing professionals during the Curricular Training, which is a stage of the process of 
professional education, conformation and consolidation of management competences, which is the object of this study. This scenery refers to a hospital institution and five wards of the municipal health net that are the fields for supervised practices for scholars as well as for the Nursing Department that is part of the graduation course of the Enfermagem da Escola de Farmácia e Odontologia de Alfenas - Centro Universitário Federal (Efoa/Ceufe)(Nursing and Dentistry School of Alfenas)- Federal University Centre (Efoa/Ceufe), which became part of the Universidade Federal de Alfenas-MG (UNIFAL-MG) Federal University of Alfenas - MG, from June 2005, all located in the city of Alfenas, in the South region of Minas Gerais.

At first, in the ideal of scientific investigation, we aim at working with all subjects involved in this study scenery, that is, the 40 scholars that developed this study setting, the 9 nurses of the hospital, and the 11 chosen in the wards of municipal services that have agreements with the Federal Institution of Higher Education, as well as the 17 professors, nurses that supervise the Curricular Training.

In the initial process to make individuals sensible, they were formally invited both by telephone, personally, and with an invitation letter.

At the same time, we present the research objectives, the importance of taking part in the study, assuring confidentiality, so as to decrease concern with future exposure. Meetings were scheduled regarding the day, time, and place, following ethical and legal aspects determined by Resolution 196/96, of the National Health Council( ${ }^{(7)}$.

It is important to stress that not all individuals return, and show up at the days and times scheduled, according to the guests' consent, only those who accepted to take part in this scientific investigation, giving their written consent were included.

Thus, the individuals of the present study were five (5) of the nine (9) nurses of the hospital, seven (7) of the eleven (11) nurses of the ambulatories with agreements, twelve (12) of the seventeen (17) nurse professors, and eleven (11) nursing scholars of the forty (40) enrolled at the Curricular Training.

Therefore, the present study had four (4) intentional samples, that of nursing scholars, that of professors, that of nurses from hospitals, and that of basic health services.

Defining the sample is qualitative research is not based on numerical criteria to ensure its representativeness. It is validated by making social individuals closer to the problem that will be investigated. Thus, with the sample gathered in this study, the object can be designed, and reflected in its several dimensions ${ }^{(8)}$.

In this investigation, we have opted for the technique of focal group to collect the empirical material, because it has the possibility of expressing the subjectivity of the research individuals, demonstrating their experiences in the field studied, through verbal reports and group discussions, conducted from December 2004 to February 2005.

The aim of the focal group is to bring about both the cognitive aspects (opinions, influences, and ideas) and the interaction aspects (conflicts, leadership, and alliances) and the experiences of social individuals of the reference group ${ }^{(6)}$.

Four meetings were held (4), in 1 of them there were the nurse scholars, in another 2 meetings there were the service nurses, one with hospital nurses and the other with those from collective health, and there was 1 meeting with professors.

Data analysis is based on the dialectic perspective, in agreement with the theoreticalmethodological reference of this investigation, which enables to study empirical data with its peculiarities, keeping in mind the historical and social context in which they are inserted. Content analysis technique is used, which tries to extract clear and latent meaning from the qualitative material collected in the discourse of individuals ${ }^{(6)}$, supported by two great bases.

Regarding education two analytical categories were identified: building the dimension of management knowledge, including the theory and practice relationship, the strategies for learning and teaching, and the competences of subjects in this process. And, also, the Pedagogical Process of the Subject according to the Curricular Guidelines encompassing the profile of professionals: the demanded profile and that which is possible, and the partnerships of the learning institutions and the services.

In the theme of work, the empirical category entails the organization of the work process in health and in Nursing, and it is divided into the management work of nurses and the institutional management policies.

\section{RESULTS AND DISCUSSION}

The flow of information collected gave an idea of the setting of management practices where the 
link between background and work, teaching and service, occurs, that is the link between the individuals of this investigation, professors, students and the working nurses. Identifying their demands, trying to overcome the limiting factors of a repetitive education and praxis, learning strategies and building ways for a transforming proposal, making adjustments of what is present and what is determined by the current Health, Education and Teaching Policies especially in this study, the teaching of Management, to conform and consolidate management competences to nurses, who are the object of the present investigation.

With the overall objective of assessing the demands and expectations of the management practices with regards to the Pedagogical Project and the strategies involving professors, students, working nurses, that may or may not favor the transforming practice, some limitations, demands and strategies are presented from the education and practice of nurses regarding the construction and consolidation of management competences of the students.

In the theme education, the building of dimensions of the management knowledge is assessed concerning the theoretical and practice relation, the teaching-learning strategies, and the individuals who are part of this process; whose knowledge should be geared towards the social commitment of the university, before the problems of the contemporary world $^{(9)}$. And, in this theme, it is considered in the Pedagogical Project, the profile of professionals that are graduating and the partnerships between education and service. Regarding the theme work, the process of the management work of nurses and the management policies of the institutions involved are presented for analysis.

In the relation theory and practice, the statements of scholars and professors, reveal that teaching is geared to care with few opportunities for management, which are focused on bureaucratic activities, providing a distorted view of the supervising role of scholars.

Additionally, during discussions, statements given by working nurses show several opportunities to develop care dimension in their governability space which they cannot perform fully, maybe because the model is focused on the work of professionals rather than on the client. To that end, Nursing has to be understood as a mean activity, that is, an instrument supporting care, and not an activity involving bureaucratic issues ${ }^{(5,10)}$.
It is characterized in all groups of individuals the education according to expertise, breaking knowledge, which goes against the general education of the National Curriculum Guidelines ${ }^{(11)}$. And, also, both professors and nurses show the need to introduce strategies encouraging critical and reflexive thinking of students, questioning the practice, to which the role of professors as facilitator or the teaching-learning process is essential, linking theory and practice, where nurses share with both their needs and challenges.

In this empirical reality, in this partnership between teaching institutions and services, the individuals mentioned that, human resources, regarding giving dimension to professors and nurses, respectively, presents a demand with limited transformation.

However, if the proposal is integration between teaching and service, aiming at building partnerships to overcome the division of power, knowledge, and experiences so that those from health services and teaching institutions can be integrated, strategies can be built in the every day life to guide the path, making changes possible so that transformation can occur.

Thus, in this focus of analysis, we can make a parallel with scholars working with trainees, regarding the activities developed for their teachinglearning process that have to be integrated with the demand for services, whose planning need to count on the active participation of all subjects involved.

Building partnerships is a challenge, however, even in the most unfavorable contexts, in the most strict and conservative institutions, there is the possibility of building a dialog with other segments, building common goals, and to some extent, sharing decisions, knowledge and resources, which is enough to enable the possibility of new subjects that can change and are open to transformation ${ }^{(12)}$.

Even though Public Policies have the discourse of transformation, and subjects have had problems to meet it, both in education and practice, determined by the demands of the resisting Hegemonic Model of Health and Education, which is still present in the institutional policies of IFES, of the Municipal Health Secretariat and of the Hospital, regarding the activities developed in the trainee system, the proposal inserted is the strategy of reflexive practice ${ }^{(13)}$, where investigation is performed together with action-reflection-action of the every day situations together with the students and nurses of 
the service. Thus, the aim is to overcome repetitive practice, finding ways for transformation in a continuous and gradual process, built from the intersubjective relations that occur everyday in the relation teaching-service, education and work, enabling students to consolidate not only technical and scientific competences but also ethical political, communicative, to develop citizenship that is essential for the work of nurses facing the paradigms in care and the flexibility of management, considering it as an instrument for care dimension ${ }^{(14)}$.

Data demonstrated the importance given by individuals to group discussion, involving students, professors, and nurses of basic care services, and those from hospital, which are involved in processes of teaching-learning, care, and management, and then it is possible to continue the action-reflectionaction that is expected for education and practice in a transforming perspective linked between teaching and service, as well as redesigning the Pedagogical Project, according to the profile required by the National Curriculum Guidelines.

The statements of students, professors, and nurses, suggest that, in practices previous to Curricular Training, students should be allocated for a longer period and in smaller groups. And, also, that both professors and students must be aware of the demands of the service, which, in our opinion, is already enough to start encouraging interaction between student-professor-nurse during the development of the practice, and in the end of each stage, as presented by nurses and professors, a feedback is given, making the partnership schoolhealth service institution stronger. It has been confirmed that building management knowledge and the adjustment of management competences occur in a two way movement, going from practice to training programs and being consolidated by the every day life due to the unpredictability of the teaching and service relationship that shape the way for transforming practice.

Human development, and thus, the movement for transformation do not depend only on the will of individuals. It is built in a continuous interaction between individuals and the society creating the need for developing competences of the dimension between knowing how to be and knowing how to live ${ }^{(15)}$. In turn, the development of citizenship, occurs at the same time as a qualification of the human condition in itself, that is made concrete by the game of civil, political, and social rights that demands effective sharing of goods, social assets and subjectivity that can be achieved through partnerships that form the dimensions of knowledge geared to life as a permanent building process ${ }^{(12)}$.

Scholars value the participation of nurses in the service to supervise training activities, and they suggest they are following up nurses in the management work of the daily routine. However, this strategy is pointed out by nurses of hospital as limiting due to issue of control of COREN (Regional Nurse Council).

To go further in this discussion it is important to base the legal aspect of service nurses to supervise Nursing students and giving them autonomy for this role, ensuring the legal aspects of linking an education institution with the health service as well as meeting the agreement and commitment term between scholars and service institution, the insurance plan, the trainee card enrolled at COREN, the Activity Plan of the student in the training field being clear about the examination system linked with the school, in locus guidelines by professors, presenting reports at the end of each stage to feed the teaching-service relationship, ensuring the commitment of the school for their education. Another essential aspect is to identify the management policy of the health institution, the Philosophy, the mission and its expectation regarding the teaching-service partnership, searching for connection between the parts involved, checked in locus by the Training Commission before the agreement is signed.

However, according to the Resolution \# 299/ 2005, in article 5, single paragraph, of the Federal Nursing Council "nurses cannot, while working in the institution where Curricular Training takes place, have at the same time the role assigned in the service and the role of supervising the training"(16). There is the question whether this measure helps or hinders the education of nurses, that should be geared to a greater teaching/service integration, to partnerships, and to the construction of the management knowledge and insertion in the reality, with the everyday activity of professional situations, where education occur together with work.

We aim at meeting the article 7 of the Resolution CNE/CES \#3/2001 that establish the National Curriculum Guidelines for the Nursing Course, which refers on mandatory Supervised Curricular Training in health services of primary and tertiary 
levels in the last two semesters of the course, making it clear in a single paragraph that "to plan the activities and the process of supervising the students, by professors, the effective participation of service nurses must be ensured, where the mentioned training is developed"(11).

In the perception of individuals, new paths can be built, both for teaching and service, in a transforming perspective, if the partnerships are strengthen, and the individuals in the intercessory spaces and times link education with work, committing themselves with making the difference, in a real and continuous exercise of citizenship.

Thus, building paths is to try to give a new meaning to "objectivity" and rethink "subjectivity" in actions, knowing that relations are not permeated by domain, but by living together and, in that, transformations occur in interaction and communion among individuals(17), thus, it is essential for consolidation of SUS, health professionals, in this study, nurses rethink the process of management work to give a new meaning for education and practice.

\section{FINAL CONSIDERATIONS}

In this empirical setting, it is explicit the need for introducing planning among individuals involved in the education and practice, that in this study, are the scholars, professors, and nurses of basic health services and of hospitals linking teaching and service.

The teaching/learning strategies must be geared to problems of the situations experienced in the every day work of the individuals involved, and it is possible that professionals being educated and those in the practice conform and consolidate management competences in a continuous process, where

\section{REFERENCES}

1. Almeida MCP. A enfermagem e as políticas de saúde. Revista Latino-am Enfermagem 1997 julho; 1(1):53-62.

2. Backes VMS. Estilos de pensamento e práxis na enfermagem: Acontribuição do estágio pré-profissional. Ijuí (SC): Ed. Unijuí; 2000

3. Ministério da Saúde (BR). Secretaria da Gestão de Trabalho e da Educação e Saúde. Caminhos para a mudança da formação e desenvolvimento dos profissionais de saúde: Diretrizes para a ação política para assegurar educação permanente do SUS. Brasília (DF): Ministério da Saúde; 2003. 4. Rios TA. Compreender e ensinar: Por uma docência da melhor qualidade. $2^{a}$ ed. São Paulo (SP): Cortez; 2001. education is seen as permanent, built during life in work and social relations, among living in society.

To that end, education and work must work simultaneously, rather than having education before work, aiming at following the requirements of the current Health and Education Policies and the Teaching of Nursing in itself where Management consolidates competences to nurses for the practice of management work where they perform the role of articulators, facilitators in the management of services and caregivers of clients.

It is learned with individuals that the profile of professionals for the transformation of practice demands competences for symbolic manipulation, for the subjectivity of relations, to overcome excessive technological maneuver, in which the "subject" is prioritized, and, thus, students are the object of teaching-learning process, the client is the object of team work. However, service nurses try to adequate work with coexisting aid and management models however; it cannot reach transforming practice due to the resistance found in the organization of health services to the Hegemonic Neoliberal Model that supports the reiterative practice.

In the 21st century, education and practice of nurses must pass through work processes of caring, management, education dimensions of scientific investigation, to take its role of articulator in the system, services and health care, in the view of integrality, teaching/service integration, meeting the demands of the population, building ways for operating at SUS. And, thus, in this study, professors must be tuned to this historical and social context, and they should meet their partners again to redesign the Pedagogical Project of the Course, making it suitable to the recommended pedagogical and assistance models.

5. Silva VR. A prática gerencial do enfermeiro em instituições hospitalares. [dissertação]. São Paulo (SP): Escola Paulista de Medicina/UNIFESP; 2000.

6. Minayo MCS. O desafio do conhecimento: pesquisa qualitativa em saúde. 6a ed. São Paulo (SP): Abrasco; 1999. 7. Ministério da Educação (BR). Lei no 9394, de 20 de dezembro de 1996. Estabelece as diretrizes e bases da educação nacional. Diário Oficial da União. Brasília (DF): Ministério da Educação; 1996. 34(248): 833-841, Seção 1. 8. Minayo MCS, Deslandes SF, Cruz Neto O, Gomes R. Pesquisa social: Teoria, método e criatividade. 19a ed. Petrópolis (RJ): Vozes; 2001.

9. Santos BS. Pela mão de Alice: O social e o político na pósmodernidade. $4^{a}$ ed. São Paulo (SP): Cortez; 1997. 
10. Greco RM. Ensinando a administração em enfermagem através da educação em saúde. Rev Bras Enfermagem 2004 julho-agosto; 57(4):504-7.

11. Conselho Nacional de Educação (CNE). Câmara de Educação Superior (CES). [homepage na internet]. Brasília (DF): Ministério da Educação; 2001 [acesso em 2005 abril 19]. Resolução CNE/CES nº.3 de 7 de novembro de 2001. Instituem diretrizes curriculares nacionais do curso de graduação em enfermagem. Disponível em: http:// www.redeunida.org.br/diretrizes/docs/enfermagem_ resolucao_0301.pdf.

12. Feuerwerker LCM, Sena R. A construção de novos modelos acadêmicos de atenção à saúde e de participação social. In: Almeida M, Feuerwerker LCM, Llanos M, organizadores. Educação dos profissionais de saúde na América Latina: teoria e prática de um movimento de mudança. Londrina (PR): UEL; 1999. p.47-82.

13. Schön DA. Formar professores como profissionais reflexivos. In: Nóvoa A. Os professores e a sua formação. Lisboa: Publicações Dom Quixote; 1992. p. 77-92.

14. Vale EG, Guedes MCV. Competências e habilidades no ensino de administração em enfermagem à luz das diretrizes curriculares nacionais. Rev Bras Enfermagem 2004 julhoagosto; 57(4):475-8.

15. Severino AJ. Filosofia. São Paulo (SP): Cortez; 1992.

16. Conselho Federal de Enfermagem (COFEN). Brasília (DF): COFEN [homepage na Internet]; 2005 [Acesso em 2006 junho 23]. Resolução no 299/2005. Dispõe sobre indicativos para a realização de estágio curricular supervisionado de estudantes de enfermagem de graduação e do nível técnico da educação profissional. Disponível em: http: www.portalcofen.gov.br/2007/materias.asp? atrickeID= 7126\&sctionID $=34$.

17. Silva AG Jr, Alves CA, Alves MGM. Entre tramas e redes: cuidado e integralidade. In: Pinheiro R, Mattos RA, organizadores. Construção social da demanda: Direito à saúde, trabalho em equipe, participação e espaços públicos. Rio de Janeiro (RJ): Abrasco; 2005. p.77-89. 